\title{
New Calcareous Nannofossil taxa from the Jurassic
}

\author{
P. R. BOWN \& M. K. E. COOPER \\ Department of Geological Sciences, University College London, London WC1E 6BT. \\ Stratigraphic Services International Limited, Guildford, Surrey GU2 5YL.
}

\begin{abstract}
Four biostratigraphically significant new calcareous nannofossil species are described, Biscutum davyi, Lotharingius contractus, Lotharingius velatus and Retecapsa incompta, together with three new combinations.
\end{abstract}

\section{INTRODUCTION}

Four new species of Jurassic calcareous nannofossil are described, together with three new taxonomic combinations. The new species are of biostratigraphical importance for an interval spanning the Lower Jurassic -Middle Jurassic boundary (see Bown et al., 1988).

\section{TAXONOMY}

The new taxa are presented as type series (holotype + isotypes) described and illustrated via scanning electron and light microscopes. It is considered expedient to utilize both these viewing techniques in the description and illustration of new nannofossil taxa (preferably using same specimen techniques, e.g. Gallagher, 1988). Together they provide the optimum amount of information concerning crystallographic construction, gross surface morphology and ultrastructure, thus promoting accurate, unambiguous description and logical, consistent classification. Holotypes and isotypes are quoted as film and frame numbers which are housed in the Postgraduate Unit of Micropalaeontology, Department of Geological Sciences, University College London. Holotype dimensions are given in brackets. Taxonomic references not given in the reference list may be obtained from Bown, 1987, and Grun and Zweili, 1980.

\section{SYSTEMATIC PALAEONTOLOGY}

Order Eiffellithales Rod, Hay and Barnard, 1971

Family Stephanolithiaceae Black, 1968 Genus Stradnerlithus Black, 1971

Remarks. The original diagnosis of Black (1971) described the central structure as a solid longitudinal bar joined to the rim by lateral branches. A slightly broader concept, including forms with a less prominent longitudinal bar or bars radiating from a central process only, is preferable at the generic level, e.g. PerchNielsen, 1985, p. 404.
Stradnerlithus geometricus (Gorka, 1957) comb. nov. Bown and Cooper

(Pl. 1, figs. 31, 36)

1957 Discolithus geometricus Gorka: 259, 279, pl. 4, fig. 8 (basionym).

1967 Corollithion derosus Lyvleve: 97, pl. 4, figs. 42, $42 \mathrm{a}$.

1969 Corollithion ellipticum Bukry: 40, pl. 18, figs. 9, 10.

1969 Zygolithus sexiradiatus Pienaar; 116, pl. 4, fig. 9, pl. 10 , fig. 9.

1971 Actinozygus geometricus (Gorka, 1957); Rood et al., 254, pl. 1, fig. 6 .

1971 Ellipsochiastus hexserratus Worsley: 1308, pl. 1, figs. 24-26.

1971 Corollithion geometricum (Gorka, 1957); Manivit, 109, pl. 5, figs. 4 and 5.

Remarks. The species name sexiradiatus Pienaar, 1969 is considered a junior synonym. The genus Corollithion Stradner 1961 was defined to include coccoliths with hexagonal outlines and is thus not suitable for the inclusion of this species. The generic concept of Stradnerlithus given in Perch-Nielsen (1985) allows the inclusion of this species, and best reflects its phylogenetic relationships.

Stradnerlithus gorodishchensis (Cooper, 1987) comb. nov. Bown and Cooper

(Pl. 1, figs. 32, 37, 38)

1987 Paractinozygus gorodishchensis Cooper: 607 -608 , fig. 1 (5-8) (basionym).

Remarks. A broad generic concept of Stradnerlithus, e.g. Perch-Nielsen (1985), allows the inclusion of this species. 
Order Podorhabdales Rood, Hay and Bernard, 1971 Family Biscutaceae Black, 1971

Genus Biscutum Black in Black and Barnes, 1959 Biscutum davyi sp. nov. Bown

(Pl. 1, figs. 16-21, 35)

Derivation of name. Named after Mr James Davy, Micropalaeontology Technician (University College London).

Diagnosis. A species of Biscutum possessing 2 distal shield cycles a (broad outer cycle and a narrow inner cycle) and a small central area spanned by a cross structure dominated by a broad longitudinal bar which tapers sharply at each end.

Holotype. UCL-2615-24 (Pl. 1, fig. 18).

Isotypes. UCL-2615-14 (Pl. 1, fig. 19), UCL-2668-28

(Pl. 1, fig. 20).

Type locality. Ilminster, Somerset.

Type level. falciferum Zone, Lower Toarcian.

Description. A broadly elliptical coccolith possessing a typical biscutacean rim (i.e. broad distal shield formed from non-imbricating radial elements; small central area with a steeply sloping edge). The distal shield consists of a broad dominant cycle constructed from around 20 elements and an inner cycle which is narrow, reaching half way up the steep central area edge. The elements of the distal shield are joined along radial sutures, with some kinking near the inner edge of the outer cycle (veeing in an anticlockwise direction). The proximal shield is considerably smaller than the distal shield, to which it is closely adpressed, and is formed from a broad cycle of non-imbricating, radial elements. At its inner edge the proximal cycle appears to interlock with a narrow second cycle which is thought to represent the base of the cycle described on the distal side as the inner distal cycle. The central area is small and almost completely filled by a cross structure made up of a prominent longitudinal bar, broad at its centre (where there is a small central process) and tapering towards its ends (running parallel to the central area edge); subsidiary transverse components complete the central complex (Pl. 1, fig. 17). In the light microscope (crossed-polars) the outer part of the shields is relatively dark but the inner cycle is distinctly bright. The cross bars are bright in certain orientations.

Dimensions. Distal shield length: 5.2-6.2 (5.8) $\mu \mathrm{m}$ width: $4.3-5.2(5.0) \mu \mathrm{m}$

Proximal shield length: $3.2-4.0 \mu \mathrm{m}$ width: $3.0-3.3 \mu \mathrm{m}$

Remarks. Biscutum davyi is a distinctive species which has only been recorded from the type locality where it has a restricted stratigraphical range in the falciferum Zone (Lower Toarcian). It is one of a relatively large number of species which diversified from the Biscutum novum (Goy, 1979) Bown 1987 root stock in the Pliensbachian and Early Toarcian, e.g. B. grandis Bown 1987, B. finchii Crux 1984, Discorhabdus striatus Moshkovitz and Ehrlich 1976, Sollasites spp. and Calyculus spp.. The central structure is particularly comparable with Sollasites pristinus Noel 1973. It is distinguished from the latter species by its very small central area (a diagnostic feature of Biscutum) and the solid longitudinal bar. In addition, $S$. pristinus does not have a prominent distal inner cycle.

Range. falciferum Zone (Lower Toarcian).

Family Retecapsaceae Grun in Grun and Allemann, 1975

Genus Retecapsa Black, 1971

Retecapsa incompta sp. nov. Bown and Cooper

(Pl. 1, figs. 22-30)

Derivation of name. Referring to the lack of lateral bars in the central area (latin incomptus = unadorned).

Diagnosis. A small species of Retecapsa with a central area cross supporting a spine; no lateral bars.

Holotype. UCL-2622-33 (Pl. 1, fig. 22).

Isotypes. UCL-2622-3 (Pl. 1, fig. 23), UCL-2622-7 (Pl. 1, fig. 24), UCL-2668-32 (Pl. 1, figs. 26).

Type locality. Brenha, Portugal.

Type level. Aalenian.

Description. A relatively small coccolith possessing a typical retecapsid rim type (i.e. distal shield horizontal or inward sloping; radiating, non-imbricating rim elements; at least two distal rim cycles including the diagnostic narrow outer cycle). The distal shield has two cycles, a broad inner cycle and a narrower, peripheral outer cycle. The inner and outer cycles are formed from 20-30 non-imbricating elements joined along radial sutures. The structural relationship between these two cycles is uncertain but proximal and side views appear to show the inner cycle lying over the outer cycle and thus revealing only a narrow outer part. The proximal cycle is unicyclic and formed from non-imbricating elements joined along radial sutures which kink near their inner edge, veeing in an anticlockwise direction. The central area is spanned by a cross structure which supports a central spine. The cross bars are oriented along the principal axes of the ellipse and are composed of elongate elements aligned along the bar's length. On the proximal side the bars have median furrows which run into a central pore, marking the position of the spine. In the light microscope (crossed-polars) the broad inner cycle is bright and the narrow outer cycle is dark. When aligned along the polarising directions the cross bars are bright with dark median lines. The bars taper towards their outer edge. 
Dimensions. Length: $5.0-5.9(5.7) \mu \mathrm{m}$

Width: $3.6-4.4(4.2) \mu \mathrm{m}$

Remarks. This species does not fit readily into any genus (due to overly restrictive generic diagnoses in this family), however, its affinities clearly lie with species of the genus Retecapsa, i.e. retecapsid rim and prominent cross-bars. The lack of additional small lateral bars (a diagnostic character) is not considered significant enough to warrant the formation of a new genus. The evolutionary proximity of this earliest species of Retecapsa to, for example, Retecapsa schizobrachiata (Gartner, 1968) Grun in Grun and Allemann, 1975 (which possesses cross bars together with 8 small lateral bars) is quite evident. Other genera of the Retecapsaceae, e.g. Polypodorhabdus and Cretarhabdus, are not appropriate as they possess more complicated central structures with multiple lateral bars and grills. $R$. incompta is biostratigraphically significant, appearing in the latest Toarcian (levesquei Zone) after a period with few or no nannofossil appearances. It is also evolutionarily important, possessing the first retecapsid rim and representing the earliest member of the subsequently diverse Retecapsaceae.

Range. levesquei Zone (Upper Toarcian) to lamberti Zone (Callovian).

Occurrence. Badenweiler (S.W. Germany) - levesquei Zone (Upper Toarcian); Bearreraig (Scotland) - concavum Zone to laeviuscula Zone (Aalenian); Clapgate Farm (S.E. England) - athleta Zone (Callovian); Escoville (N. France) - macrocephalus Zone (Callovian); Geisingen (S.W. Germany) - opalinum Zone to murchisonae Zone (Aalenian); Port-en-Bessin (N. France) - Lower Bathoniain; Ringsheim (S.W. Germany) - Lower Bajocian; Sainte Honorine (N. France) - laeviuscula Zone to parkinsoni Zone (Bajocian); BGS Seabarn Farm Borehole (S. England) - Upper Bajocian to Upper Bathonian (aspidoides Zone); BGS Winterbourne Kingston Borehole (S. England) Lower Bajocian.

Order Watznaueriales Bown, 1987

Family Watznaueriaceae Rood, Hay and Barnard, 1971 Genus Lotharingius Noel, 1973

Lotharingius contractus sp. nov. Bown and Cooper (Pl. 1, figs. 1-7)

Derivation of name. Referring to the small central area of this coccolith (latin contracta = narrow).

Diagnosis. A species of Lotharingius with a very small central area almost entirely filled by cross bars orientated along the principal axes of the ellipse; few or no lateral bars.

Holotype. UCL-2645-34 (Pl. 1, fig. 2).

Isotypes. UCL-2645-27 (Pl. 1, fig. 1), UCL-2677-13 (Pl. 1, fig. 5).
Type locality. Brenha, Portugal.

Type level. Aalenian.

Description. A relatively large, broadly elliptical coccolith with a watznauerian rim structure (see Bown, 1987. p.66 for full description of rim). The central area is small and almost completely filled by cross bars orientated with the principal axes of the ellipse and a central process which may represent a spine base. A number of specimens show additional lateral bars filling the small quadrants left by the principal cross bars. Dimensions: Rim length: $5.7-7.5(7.2) \mu \mathrm{m}$ width: $4.8-6.9(6.0) \mu \mathrm{m}$

Remarks. Lotharingius contractus has a first occurrence, in northern Europe, in the murchisonae Zone (Aalenian) and represents a significant biohorizon. The species is an intermediate form between typical Lotharingius species (e.g. L. sigillatus (Stradner, 1961) Prins in Grun et al. 1974, L. crucicentralis (Medd, 1971) Grun and Zweili, 1980) which have wide central areas spanned by cross and lateral bar complexes, and typical Watznauria species (e.g. W. britannica (Stradner, 1963) Reinhardt 1964, W. barnasae (Black, 1959) PerchNielsen 1968, W. fossacincta (Black, 1971)) which have reduced or closed central areas with no central structures or a maximum of one central bar. Lotharingius contractus in evolving from $L$. sigillatus or $L$. crucicentralis underwent considerable reduction in central area which resulted in a shrinking of the central cross complex and loss of most or all of the lateral bars. The gradual loss of the long axis bar to form $W$. britannica has been observed in the light microscope.

Range. murchisonae Zone (Aalenian) to macrocephalus Zone (Callovian).

Occurrence. Bearreraig (N.W. Scotland) - concavum Zone (Aalenian) to laeviuscula Zone (Bajocian); Eichberg (S.W. Germany) - Lower Bajocian; Escoville (N. France) - discus Zone (Upper Bathonian) to macrocephalus Zone (Callovian); Geisingen (S.W. Germany) - murchisonae Zone (Aalenian); Port-enBessin (N. France) - Lower Bathonian; Ringsheim (S.W. Germany) - Lower Bajocian; Sainte Honorine (N. France) - laeviuscula Zone to parkinsoni Zone (Bajocian)

\section{Lotharingius velatus sp. nov. Bown and Cooper}

(PI. 1, figs. 8-15)

Derivation of name. Referring to the covered central area (latin, velatus $=$ cover).

Diagnosis. A species of Lotharingius with a wide central area, closed by a granular plate.

Holotype. UCL-2689-25 (Pl. 1, fig. 8).

Isotypes. UCL-2689-16 (Pl. 1, fig. 9), UCL-2689-3 (Pl. 1, fig. 10), UCL-2690-3 (Pl. 1, fig. 11), UCL-2690-19 (Pl. 1, fig. 13). 


\section{Explanation of Plate 1 \\ $\mathrm{c}-\mathrm{p}=$ cross-polars, $\mathrm{p}-\mathrm{c}=$ phase contrast.}

Figs. 1-3, 5-7. Lotharingius contractus sp. nov.

1. isotype: distal view, UCL-2645-27, Brenha (Aalenian) $(\times 4840)$.

2. holotype: distal view, UCL-2645-34, Brenha (Aalenian) $(\times 4235)$.

3. distal view, UCL-2622-6, Brenha (Aalenian) $(\times 3880)$.

5. isotype: c-p, UCL-2677-13, Ringsheim (10), sauzei Zone, UCL-2677-13 $(\times 2440)$.

6. c-p, UCL-2677-3, Brenha (Aalenian) $(\times 1855)$.

7. as 1.6 , p-c, UCL-2622-6 ( $\times 1665)$.

Fig. 4. Lotharingius cf. contractus sp. nov.

4. distal view, UCL-2622-2, Brenha (Aalenian) $(\times 5360)$.

Figs. 8-15. Lotharingius velatus sp. nov.

8. holotype: distal view, UCL-2689-25, St. Honorine (Bajocian) $(\times 5000)$.

9. isotype: distal view, UCL-2689-16, St. Honorine (Bajocian) $(\times 4410)$.

10. isotype: distal view, UCL-2689-3, St. Honorine (Bajocian) $(\times 6135)$.

11. isotype: proximal view, UCL-2690-3, Port-en-Bessin (Bathonian) $(\times 5085)$.

12. p-c, UCL-2690-20, Port-en-Bessin (Bathonian) $(\times 2270)$.

13. isotype: as 1.12 , c-p, UCL-2690-19.

14. as 1.12, c-p different orientation, UCL-2690-21.

15. c-p, UCL-2690-23, Port-en-Bessin (Bathonian) $(\times 2270)$.

Figs. 16-21, 35. Biscutum davyi sp. nov. Bown

Ilminster, falciferum Zone.

16. distal view, UCL-2615-27 ( $\times 5360)$.

17. distal view, central area, UCL-2615-31 $(\times 14135)$.

18. holotype: distal view, UCL-2615-24 $(\times 5260)$.

19. isotype: proximal view, UCL-2615-14 $(\times 4920)$.

20. isotype: $c-p$, UCL-2668-28 $(\times 2950)$.

21 . as 1.21 , p-c, UCL-2668-29.

35. as 1.18 , distal oblique view, UCL-2615-26 $(\times 6135)$.

Figs. 22-30. Retecapsa incompta sp. nov.

Brenha, Aalenian.

22. holotype: distal view, UCL-2622-33 $(\times 5345)$.

23. isotype: distal view, UCL-2622-3 $(\times 5770)$.

24. isotype: distal view, UCL-2622-7 $(\times 6095)$.

25. proximal view, UCL-2622-28 $(\times 6130)$.

26. isotype: c-p, UCL-2668-32 $(\times 2260)$.

27. as $1.26, \mathrm{p}-\mathrm{c}, \mathrm{UCL}-2668-33(\times 2110)$.

28. c-p, UCL-2668-14 $(\times 3175)$.

29 . as 1.28 , UCL-2668-15 $(\times 2870)$.

30 . as 1.22 , distal oblique view, UCL-2649-1 $(\times 6000)$.

Figs. 31 and 36. Stradnerlithus geometricus (Gorka, 1957) comb. nov.

31. distal view, UCL-1502-21, Gorodishche (Kimmeridgian) $(\times 11350)$.

36. p-c, UCL-1507-5, Gorodishche (Volgian) $(\times 5600)$.

Figs. 32, 37, 38. Stradnerlithus gorodichshensis (Cooper, 1987) comb. nov.

Gorodishche, Kimmeridgian.

32. distal view, UCL-1502-7 $(\times 6550)$.

37. c-p, UCL-1507-25 $(\times 3000)$.

38. as 1.37 , UCL-1502-24.

Figs. 33 and 39. Watznaueria manivitae Bukry 1973.

33. distal view, UCL-1536-4, DSDP Site 261 (Tithonian) $(\times 2010)$.

39. c-p, UCL-2695-1, Clapgate Farm Borehole (jason Zone, Callovian) $(\times 845)$.

Figs. 34, 40, 41. Watznaueria fossacincta (Black, 1971) comb. nov. Bown.

34. distal view, UCL-1399-13, Nettleton (Ryazanian) $(\times 5040)$.

40. c-p, UCL-2695-15, Dorset Coast (Kimmeridgian) $(\times 2050)$.

41. as $1.40, \mathrm{p}-\mathrm{c}, \mathrm{UCL}-2695-14(\times 1830)$. 

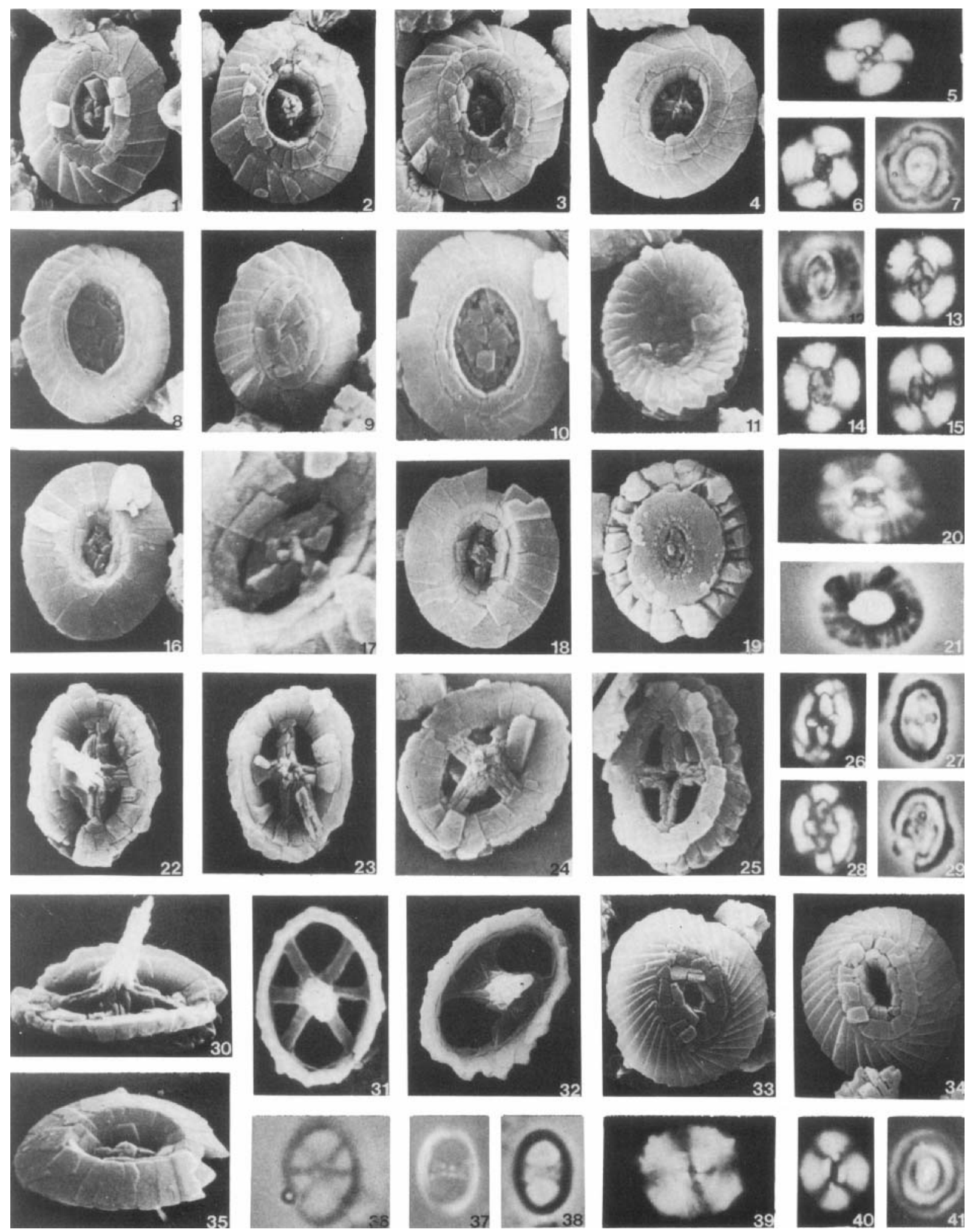
Type locality. Sainte Honorine-des-Pertes, N. France. Type level. humphresianum - parkinsoni Zone, Bajocian.

Description. A broadly elliptical coccolith with a Lotharingius rim (see Bown, 1987, p.66). The wide central area is clearly delineated and filled by a granular plate. The plate may be formed from relatively equidimensional grains or have a longitudinal component formed from coarser grains with finer grains around the edge of the central area; perforations may exist at the junction between these two grain types (PI. 1, fig. 10). In the light microscope (crossed-polars) the rim is characteristically bright with four curving isogyres. The central area is filled by a plate which appears slightly darker than the rim. The plate appears to be homogenous in structure but in certain orientations four dark isogyres form a cross approximately parallel to the principal axes of the elliptical centre (P1. 1, figs. $13,15)$. There is some indication of a cross-like basis to the structure.

Dimensions: Length: $5.7-6.8(6.0) \mu \mathrm{m}$

Width: $4.5-5.6(4.8) \mu \mathrm{m}$

Remarks. This species is placed in the genus Lotharingius as its ellipticity, size, rim structure and central area form are identical to that seen in Lotharingius sigillatus and $L$. crucicentralis. In addition, the central plate also shows signs of an antecedent and diagnostic Lotharingius central cross structure. A morphological development comprising infilling of the central bars to form an imperforate plate is quite conceivable.

Range. concavum Zone (Aalenian) to macrocephalus Zone (Callovian).

Occurrence. Bearreraig (N.W. Scotland) - concavum Zone (Aalenian) to laeviuscula Zone (Lower Bajocian); Escoville (N. France) - discus Zone (Upper Bathonian) to macrocephalus Zone (Callovian); Porten-Bessin (N. France) - Lower Bathonian; BGS Seabarn Farm Borehole (S. England) - Upper Bajocian to Lower Bathonian; BGS Winterbourne Kingston Borehole - Lower Bajocian to Lower Bathonian.

Genus Watznaueria Reinhardt, 1964

Watznaueria fossacincta (Black, 1971) comb. nov. Bown

(Pl. 1, figs. 34, 40, 41)

1971 Ellipsagelosphaera fossacincta Black: 399, pl. 30, fig. 8 (basionym).

1975 Ellipsagelosphaera keftalrempti Grun in Grun and Allemann: 161-162, text-fig. 7, pl. 2, figs. 5, 6.

1980 Ellipsagelosphaera fossacincta Black; Grun and Zweili, 253-254, text-fig. 11, pl. 2, figs. 4, 5.

Remarks. The synonomy list for this species given by Grun and Zweili (1980) illustrates the confusion which has arisen over the naming of these common watznauerian coccoliths, which possess a relatively small and vacant central area. The most appropriate valid name is fossacincta Black, 1971. The species is placed in Watznaueria, as Ellipsagelosphaera is considered to be a junior synonym of the former genus. Both generic names were introduced within a year of one another (Reinhardt, 1964; Noel, 1965) and applied to coccoliths with identical rim structures, and both included coccoliths with small, vacant central openings. The perpetuation of this division appears unnecessary.

\section{ACKNOWLEDGEMENTS}

We wish to thank Dr A. R. Lord for assistance with the manuscript and Mr J. Davy for technical help. We gratefully acknowledge the research support of the Leverhulme Trust (PRB) and Stratigraphical Services Limited (MKEC).

\section{Manuscript received June 1988}

Revised manuscript accepted January 1989

\section{REFERENCES}

Black, M. 1971. Coccoliths of the Speeton Clay and Sutterby Marl. Proc. York. geol. Soc., York, 38, 381-424.

Bown, P. R. 1987. Taxonomy, evolution and biostratigraphy of late Triassic and Lower Jurassic calcareous nannofossils. Special Papers in Palaeontology, Oxford, 38, 118pp.

Bown, P. R., Cooper, M. K. E., and Lord, A. R. 1988. A calcareous nannofossil biozonation scheme for the early to mid Mesozoic. Newsl. Stratgr., Berlin-Stuttgart, 20 (2), 91-114.

Gallagher, L. 1988. A technique for viewing the same nannofossil specimen in light microscope and scanning electron microscope using standard preparation materials. $J l$. Micropal., London, 7 (1), 53-57.

Grun, W. and Zweili, F. 1980. Das kalkige Nannoplankton der Dogger-Malm-Grenz im Berner Jura bei Liesberg (Schweiz). Jb. geol. Bundesanst. Wien, Vienna, 123, 231-341.

Moshkovitz, S. and Ehrlich, A. 1987. Watznaueria manivitae - Taxonomic problems and distribution in the JurassicLower Cretaceous sediments of Israel and other Tethyan areas. INA Newsl. London, 9, 110-115.

Noel, D. 1965. Sur les coccolithes du Jurassique europeen et d'Afrique du Nord. Essai de classification des coccolithes fossiles, Editions du CNRS, Paris, 209pp.

Perch-Nielsen, K. 1985. Mesozoic calcareous nannofossils in Bolli, H. M., Saunders, J. B. and Perch-Nielsen, K. (eds.). Plankton Stratigraphy, Cambridge, 329-426.

Reinhardt, P. 1964. Einige Kalkflagellaten-Gattungen (Coccolithophoriden, Coccolithineen). Monatsber. Dt. Akad. Wiss. Berlin, Berlin, 6, 749-759. 